\title{
Effect Of Servicescape And Customer Experience On Social Location Marketing (Case Study At Café In Medan)
}

\author{
Syafrizal Helmi Situmorang \\ Dept. Of Management \\ Faculty Economy And Business \\ University of Sumatera Utara \\ Medan, Indonesia \\ shelmi09@gmail.com
}

\author{
Ahmad Azmi \\ Dept. Of Management Faculty Economy And Business \\ University of Sumatera Utara \\ Medan, Indonesia \\ ahmadazmi1994@gmail.com
}

\author{
Hardi Mulyono \\ Dept. Of Management \\ Faculty Economy \\ University of Muslim Nusantara Alwashliyah \\ Medan, Indonesia \\ hardisurbakti@gmail.com
}

\begin{abstract}
Nowadays, a cafe is becoming a trend and growing rapidly in Medan. There are numerous people spend their time to socializing in cafes is part of the current life style. Therefore, cafe owners compete in offering new cafe concept to attract customers. To gain competitiveness and attractiveness, cafe must possess the interesting servicescape and be providing good impression toward customers in a cafe. In the social media era, people can communicate and share their experience with other people easy. The interesting cafe which shares memorable experience will be shared and promoted through social media. The purpose of this research is to analyze the influence of servicescape and customer experience on social location marketing. Data were collected through interview by using questioners. This research is conducted at 10 cafes in Medan. Data were analyzed by using smartpls 3.0. The result showed that the most frequent users of social media is Instagram. Customers will share the pictures of cafes' location which have the interesting servicescape. It indicates there is a strong influence between servicescape on customer experience and social location marketing.
\end{abstract}

Keywords-:Servicescape, Customer Experience, Social Location Marketing, Social Media

\section{Introduction}

Increased incomes lead to changes in people's lifestyles.BPS noted Indonesia's economic growth during 2016 reached 5.02 percent.This figure is higher than the previous year which amounted to 4.88 percent.With the improvement of economic conditions, per capita income or the average Indonesian people rose to Rp 47.96 million per year or close to $\mathrm{Rp} 4$ million per month. This rise raises the democratization of consumption [1] and the shift in urban lifestyles [2].
In recent, Hanging out at a cafe is a trend of adolescent and executive lifestyle. Competition in the cafe has increased. Traditional cafe have faced and pressure from the alternative or modern cafe. The modern cafe offers and creates more intimate and innovative experiences to a visitor with an emphasis on strategic location, the new concept, and social environment, maximising the interaction between customers, working space, varied drinks and food menus, different ways of serving and Good atmosphere. studied by [3] Millennials are driving changes in the country's eating behaviors with their approach to food choice and preparation.

In Medan, many new cafes are appearing and spreading all over the place but not all cafes in Medan have loyalty customers. This causes a high competition among cafe. In order for the cafe to have appeal, the cafe must have good physical environments such as floor plans, environmental conditions, air temperature, air quality, noise, music, decorating style and more. Researchers devoted much effort to understanding the effects of the physical environment on consumer such as [4] recognized "tangibles" as playing a role in customer response, and [5] pointed out that consumption settings are comprised of both physical and social elements. [6] presented a conceptual framework to study the impact of physical surroundings on customer (and employee) behavior in service settings. She proposed the three dimensions of servicescape: (1) ambient conditions; (2) spatial layout and functionality; and (3) signs, symbols, and artifacts affect consumer attitudes and behaviors. 
Exciting servicescape will give customers a good impression.

Cafe managers must pack their products and services not only offering benefits and cost but also offering a unique experience by incorporating elements that can provide value to customers in terms of positive experience and emotional. Experiences occur at various information collection, decision, and consumption stages. Lasalle and Britton (2002)[7] have presented an experience engagement model consisting of five stages such as Discover, Evaluate, Acquire, Integrate, and Extend. [8] present a "brand touchpoint experience including pre-purchase, purchase, and post-purchase experience phases,

[9] Explain The experience concept raises several consumer research issues. For example, How are experiences remembered? [10] [11] can consumers have positive and negative experiences at the same time? [12] How do they process experiential attributes? [13] can experiences be rational? [14] Research on the importance of value for customers has been researched by [15] [16].

Experiential Value may be interactive, relative, liked, personal, and may change dynamically as the experience accumulates. On the other hand, through social media activities, everyone can communicate and share experiences with others easily. Through social media, they can obtain and convey various information needed anytime and anywhere. Currently, social media is getting more advanced with the addition of check in the feature where social media users can share social location. Social location sharing is happening to your product, service, venue, and location whether you are active or not. The process of utilizing social location sharing tools as a marketing channel is known as social location marketing.

According to [17], Social location marketing is bringing businesses closer to their customer's and potential customers than any other marketing tool in recent history. For examples when users check in at a specific location, they are publicly declaring an affinity with that location. They are making the statement that they use this location as part of their lives. They are telling the people in their networks, all of whom they have selected to share with, that this is a place they go to. The reason for sharing has an element of selfishness and they want their network to be aware that they can afford, gain entry to, or otherwise be associated with a certain location.

This paper aims to fill this research gap in servicescape, customer experience, and social location marketing. The results of this study have theoretical and practical implications. First, influence the servicescape, customer experience to social location marketing by analyzing different types of servicescape cafe, experience levels, social media choice; and second these findings can help cafe managers to improve servicescape design and create a memorable experience.

\section{Literature Review}

\section{A. Servicescape}

The servicescape is defined as an organization's physical facility or the environment, where the service is offered [18]. the servicescape framework originates from research conducted in environmental psychology [19], [20] pointed out four sensory design dimensions atmospherics (sight, sound, scent, and touch) will positively influence buyers' emotions and increase the likelihood of a purchase.The atmospherics of service, which can have a strong impact on customers' perceptions of the service experience. [6] conceptualized the existence of three types of servicescape framework (1) ambient condition, (2) spatial layout and functionality (3) signs, symbols and artifacts. Ambient conditions are composed of temperature, quality of air, voice, music, smell, etc., whereas space/function is composed of design, decoration and business equipment. Signs, symbols, and artifacts are used in a physical environment with the aim of transmitting what is necessary for users or for enabling communication. Combination of three types of servicescape framework will activate internal cognitive, emotional and physiological responses in customers and employees

Based on the servicescape model, numerous empirical studies have been conducted that focus on one or several variables of the service environment such as the following:music, scent or signage and their effects on customer expenditures [21] behavioural effects due to colour and light [22], Background music can influence what people buy and how long they stay in the store. Generally, soft music gets people to stay longer and fast music makes people move along [23], perceived waiting time [24]; loyalty intentions [25]; or perceived quality [26]. Interior design issues (layout, equipment, and décor) and the exterior physical environment, emphasizing sign, parking and landscape attributes [27].

Servicescape is built and designed is important for particular target markets. The servicescape concept also includes the layout and placement of the products or service. understands how to create a servicescape that strongly influences customer satisfaction and experience. Servicescape can be used as a tool for making experience evaluations of customers easier [28]. Now, in digital era, servicescape concepts can be adapted to digital media to support customer interaction [29] 


\section{B. Customer experience}

[30] presented five types of experience marketing approaches: "sense," "feel," "think," "act," and"relate." (1) Sense marketing" appeals to consumers'senses (sight, sound, touch, taste, and smell). (2) Feel marketing" appeals to customers' inner feelings and emotions, ranging from mildly positive moods linked to a brand to strong emotions of joy and pride. (3) Think marketing" appeals to the intellect in order to deliver cognitive, problem-solving experiences that engage customers creatively. (4) Act marketing" targets physical behaviors, lifestyles, and interactions. (5) Relate marketing" creates experiences by taking into account individuals' desires to be part of a social context.

Many researchers used the concept of "experience" in the hospitality industry such as agencies, restaurants or hotels where services are commonly used [31]. The issue of experience, where it is argued that much of the customer value is the outcome of service experiences [32]; [33], and that a company should, therefore, orchestrate customer experiences that render value whenever customers interact with resources that the company provides, such as the servicescape. The term "service experience" refers to the customer's personal experience of the service process as a result of interactions with the service organization [34].

\section{Social Location Marketing}

Customer experiences may encourage customers to search and find more information about business and make comparisons between other competitors and avoid unexpected risks [35].Customers having positive image perceptions after their experiences demonstrate positive revisiting intention [36] or recommendation intention [37]. They will share their experience to family and relative.The internet allows consumers to share all types of consumption experiences including those related to locations such as restaurants, holiday places, and concerts. [38].

Increasing use of social location sharing tools, customers gain recommendations, comparisons, even reviews of products, services, and so on from their networks. social location sharing such as Twitter, Facebook, LinkedIn, Path or Instagram has become a normal part of the consideration. From the marketing research and consumer behavior perspectives, social location marketing activities are closely related to consumption (In some cases, they are mainly consumption oriented [39].

[40] studied predictors of internet use, and their factor analysis yielded five motives: interpersonal utility, passing time, information seeking, convenience, and entertainment. [41] also analyzed motivations to use the internet compared to traditional media and identified ten clusters of motivations: information, learn, play, leisure, persuasion, social bonding, relationship maintenance, problem-solving, status, and insight. According to [17], process competitions based on social location sharing are already starting to appear. Users of social location sharing tools will be the ones who benefit from the additional offers and marketing efforts from a business.

\section{Methodology}

Research used questionnaire (quantitative research) in order to measure the influence servicescape and customer experience to social location marketing. The study questionnaire benefited from the [6] in regard to the statements used in the servicescape measurement. Questionnaire Benefited from the studies of [30] in regard to the statements used in the customer experience measurement. Questionnaire. Benefited from the studies of [17] in regard to the statements used in the social location marketing measurement. Servicescape was measured with 9 statements, customer experience was measured with 14 statements, social location was measured with 4 statement. A five-point Likert-type scale was used for all statements in this section.

\section{Data collection and sample}

The present study was carried out on customers of a cafe in Medan. Questionnaires were delivered to 10 cafes in Medan with Sample size 150 Respondents were selected with convenience sampling.

Data screening and analysis

This study practices partial least square (PLS) to test a hypothesis with structural equation model (SEM). PLS is considered an approach which can provide much value for casual inquiry in communication-related and behavioral research fields [42]. Besides, PLS is powerful in modeling which allows for complex models that include latent (unobserved) variables, formative variables, chains of effects (meditation), and multiple group comparisons of these more complex relationships. PLS has the capability to calculate t-values through a technique called bootstrapping if the data are normally distributed and samples are independent.SEM "is particularly useful in testing theories that contain multiple equations involving dependency relationships" [43]. However, before models were tested, a normal distribution assumption was checked because the maximum likelihood method was used in estimating both the measurement model and structural model.

Table 1. Demographic Profile of Respondents

\begin{tabular}{|c|c|c|}
\hline & Frequency & Percent \\
\hline \multicolumn{3}{|l|}{ Gender } \\
\hline Men & 73 & 48.7 \\
\hline Women & 77 & 51.3 \\
\hline Total & 150 & 100.0 \\
\hline Age & & \\
\hline
\end{tabular}


Table 1, cont

\begin{tabular}{|l|l|l|}
\hline$<20$ year & $\mathbf{5 5}$ & 36.7 \\
\hline 21-30 year & $\mathbf{6 3}$ & 42.0 \\
\hline 31-40 year & 22 & 14.7 \\
\hline 41-50 year & 5 & 3.3 \\
\hline 51> year & 5 & 3.3 \\
\hline Total & 150 & 100.0 \\
\hline Occupation & & \\
\hline Student & 13 & 8.7 \\
\hline College & $\mathbf{6 5}$ & 43.3 \\
\hline Government employees & 9 & 6.0 \\
\hline Private employees & $\mathbf{2 4}$ & 16.0 \\
\hline Businessman & $\mathbf{2 4}$ & 16.0 \\
\hline Etc & 15 & 10.0 \\
\hline Total & 150 & 100.0 \\
\hline Frequency to the café / Month & & \\
\hline 1-2 times & $\mathbf{5 0}$ & 42.7 \\
\hline 2-3 times & $\mathbf{6 4}$ & 33.3 \\
\hline More than 4 times & 36 & 24.0 \\
\hline Total & 150 & 100.0 \\
\hline Social location Media & & \\
\hline Facebook & $\mathbf{3 6}$ & 24.0 \\
\hline Instagram & $\mathbf{8 0}$ & 53.3 \\
\hline Path & 17 & 11.3 \\
\hline Line & 9 & 6.0 \\
\hline Whatsapp & 8 & 5.3 \\
\hline Total & 150 & 100.0 \\
\hline & & \\
\hline
\end{tabular}

Table 1. Referring to the Table 1, Gender group of male respondents as much as 73 and female gender respondents were 77. Group age, Dominant Respondents under age < 20 years (55) and 21-30 years (63). Group occupation, Dominant Respondents is college (65)., Dominant Respondent, frequencies visited the cafe 2-3/month (64). Dominant respondents using social media for sharing location is Instagram.

Table 2

Descriptive variable

\begin{tabular}{|l|l|l|l|l|l|}
\hline \multicolumn{2}{|l|}{ Servicescape } & \multicolumn{2}{l|}{$\begin{array}{l}\text { Customer } \\
\text { Experience }\end{array}$} & $\begin{array}{l}\text { Social } \\
\text { Marketing }\end{array}$ \\
\hline & Mean & & Mean & & Mean \\
\hline $\begin{array}{l}\text { Ambient } \\
\text { Condition }\end{array}$ & 4.14 & Sense & 4.09 & Searching & 3.90 \\
\hline $\begin{array}{l}\text { Spatial } \\
\text { Layout }\end{array}$ & 4.26 & Feel & 4.05 & Finding & 3,82 \\
\hline $\begin{array}{l}\text { Sign, } \\
\text { Symbols } \\
\text { and } \\
\text { Artefack }\end{array}$ & 4.28 & Think & 4.1 & Check in & 3,76 \\
\hline & & Act & 4 & Sharing & 3.79 \\
\hline & & Relate & 4.09 & & \\
\hline
\end{tabular}

According to Table 2, in variable servicescape, all respondent agree that dimension ambient condition is good (scale 3.4-4.2), spatial layout, sign/symbol all cafe is very good (scale 4,2-5.0). All dimension of Customer Experience ( sense, feel, think, Act and Relate) are good. It means customer agree that cafe gave memorable experience and positive emotion. All dimension of social location marketing ( Searching, finding, check in and sharing) are good. It means a customer has used social media as a tool for social location.

Measurement model

First, the measurement model was tested for convergent validity. This was assessed through factors loadings, composite reliability (CR), and average variance extracted (AVE) [44]. Table 3 shows that all item in outer loadings exceeded and composite reliability values, which depict the degree to which the construct indicators indicate the latent construct. [44] said recommended of value must be above 0.7 , while average variance extracted, which reflects the overall amount of variance in the indicators accounted for by the latent construct, exceeded the recommended value of $0,5[44]$

Table 3.

Validity and Reliability for Constructs

\begin{tabular}{|l|l|l|l|}
\hline & $\begin{array}{l}\text { Outer } \\
\text { Loading }\end{array}$ & $\mathrm{AVE}^{\mathrm{a}}$ & $\mathrm{CR}^{\mathrm{b}}$ \\
\hline Servicescape & & 0.559 & 0.921 \\
\hline Ambient Condition & & 0.824 & 0.949 \\
\hline The café temperature is appropriate & 0,917 & & \\
\hline The lighting at the café is right & 0,851 & & \\
\hline The café is kept clean & 0,942 & & \\
\hline Harmony of music in the café fun & 0,919 & & \\
\hline Spatial Layout & & 0.731 & 0.890 \\
\hline The café layout is unique & 0,873 & & \\
\hline The layout of room well arranged & 0,798 & & \\
\hline $\begin{array}{l}\text { The arrangement of the room was made very } \\
\text { creative }\end{array}$ & 0,890 & & \\
\hline Sign, Symbols, artifacts & & & \\
\hline $\begin{array}{l}\text { The café name board is clearly visible at the } \\
\text { café }\end{array}$ & 0,875 & & \\
\hline The sign ofcafé & 0,828 & & \\
\hline Customer Experience & & 0.564 & 0.949 \\
\hline Sense & & 0.739 & 0.919 \\
\hline $\begin{array}{l}\text { The design and layout of the café is } \\
\text { interesting }\end{array}$ & 0,808 & & \\
\hline $\begin{array}{l}\text { The atmosphere of the café room is cozy and } \\
\text { cool }\end{array}$ & 0,853 & & \\
\hline The menu presentation is interesting & 0,895 & & \\
\hline The taste of the food served is interesting & 0,879 & & \\
\hline Feel & & 0.770 & 0.909 \\
\hline feel a relaxed atmosphere & 0,875 & & \\
\hline Friendly café employee service & 0,871 & & \\
\hline $\begin{array}{l}\text { Facilities (wifi, toilets, parking) add to the } \\
\text { comfort }\end{array}$ & 0,886 & & \\
\hline Think & & 0.694 & 0.901 \\
\hline Have a diverse menu innovation & 0,834 & & \\
\hline $\begin{array}{l}\text { The reputation of café influences consumer } \\
\text { confidence }\end{array}$ & 0,829 & & \\
\hline Affordable Prices for food and drink & 0,830 & & \\
\hline Best choice for hangout place & 0,839 & & \\
\hline Act & & 1.000 & 1.000 \\
\hline well information through social media & 1,000 & & \\
\hline Relate & & 0.790 & 0.883 \\
\hline place to hang out of community & 0,870 & & \\
\hline lifestyle trends of community & 0,908 & & \\
\hline Social Location Marketing & & 0.821 & 0.948 \\
\hline
\end{tabular}


Table 3, cont

\begin{tabular}{|l|l|l|l|}
\hline Searching & & 1.000 & 1.000 \\
\hline $\begin{array}{l}\text { find out about café based on friend } \\
\text { recommendation from social media }\end{array}$ & 1.000 & & \\
\hline Finding & & 1.000 & 1.000 \\
\hline $\begin{array}{l}\text { looking for café location with help of google } \\
\text { map }\end{array}$ & 1.000 & & \\
\hline Check-in & & 1.000 & 1.000 \\
\hline $\begin{array}{l}\text { check in the location of café through social } \\
\text { media }\end{array}$ & 1.000 & & \\
\hline Sharing & & 1.000 & 1.000 \\
\hline $\begin{array}{l}\text { always postingand sharing activity at the café } \\
\text { throughsocial media }\end{array}$ & 1.000 & & \\
\hline
\end{tabular}

Structural model

SmartPLS 3.0 was used to test the structural model and hypotheses [45]. A bootstrapping produce with 1000 iterations was performed to examine the statical significance of the weights of sub-constructs and the path coefficients.

Table 4

R Square

\begin{tabular}{|l|l|l|l|l|l|}
\hline & $\begin{array}{l}\text { Original } \\
\text { Sample } \\
(\mathrm{O})\end{array}$ & $\begin{array}{l}\text { Sample } \\
\text { Mean } \\
(\mathrm{M})\end{array}$ & $\begin{array}{l}\text { Standard } \\
\text { Deviation } \\
(\text { STDEV })\end{array}$ & $\begin{array}{l}\text { S } \\
\text { Statistics } \\
(\mid \mathrm{O} / \mathrm{STDE} \\
\mathrm{V} \mid)\end{array}$ & $\begin{array}{l}\mathrm{P} \\
\text { Val } \\
\text { ues }\end{array}$ \\
\hline $\begin{array}{l}\text { Customer } \\
\text { Experience }\end{array}$ & 0.577 & 0.575 & 0.064 & 9.034 & $\begin{array}{l}0.0 \\
00\end{array}$ \\
\hline $\begin{array}{l}\text { Social } \\
\text { Location } \\
\text { Marketing }\end{array}$ & 0.316 & 0.320 & 0.064 & 4.928 & $\begin{array}{l}0.0 \\
00\end{array}$ \\
\hline
\end{tabular}

The hypothesized relationship in the structural model was tested. Table 6 shows the results of the analysis. The corrected R2s in table 5 refers to the explanatory power of the predictor variables on the respective construct. Customer Experience variable is $57.7 \%$ which means that it is included in the Strong category. While the remaining $42.3 \%$ is explained by other variables outside the research model and Social Location Marketing variable is $31.6 \%$ which means that it is included in a weak category. While the remaining $68.4 \%$ is explained by other variables outside the research model.

In addition, the complete results of the structural model and hypotheses testing are presented in table 7 . All the three hypotheses $(\mathrm{H} 1, \mathrm{H} 2, \mathrm{H} 3)$ were strongly supported indicating that customer's perceptions of servicescape and customer experience are good predictors of social location marketing.

Table 5. Path coefficients

\begin{tabular}{|l|l|l|l|}
\hline & $\begin{array}{l}\text { Original } \\
\text { Sample (O) }\end{array}$ & $\begin{array}{l}\text { T Statistics } \\
(\mid \mathrm{O} / \text { STDEV|) }\end{array}$ & $\begin{array}{l}\text { P } \\
\text { Valu } \\
\text { es }\end{array}$ \\
\hline $\begin{array}{l}\text { Customer Experience -> } \\
\text { Social Location Marketing }\end{array}$ & 0.267 & 2.628 & $\begin{array}{l}0.00 \\
9\end{array}$ \\
\hline $\begin{array}{l}\text { Servicescape -> Customer } \\
\text { Experience }\end{array}$ & 0.760 & 17.855 & $\begin{array}{l}0.00 \\
0\end{array}$ \\
\hline $\begin{array}{l}\text { Servicescape -> Social } \\
\text { Location Marketing }\end{array}$ & 0.332 & 3.874 & $\begin{array}{l}0.00 \\
0\end{array}$ \\
\hline
\end{tabular}

Based on the above table explains that the influence of Customer Experience on social location marketing ( $\mathrm{p}=0.00$ $<0.05$ ) then $\mathrm{H} 0$ rejected $\mathrm{H} 1$ accepted, meaning there is a positive and significant influence between Customer Experience with Social Location Marketing, Based on the above table explains that the influence between Servicescape to Customer Experience $(p=0.00<0.05)$ then $\mathrm{H} 0$ rejected $\mathrm{H} 1$ accepted, meaning there is a positive and significant influence between Servicescape with Customer Experience and Based on the above table explains that the influence between Servicescape to Social Location Marketing $(\mathrm{p}=0.00<0.05)$ then $\mathrm{H} 0$ rejected $\mathrm{H} 1$ accepted, meaning there is a positive and significant influence between Servicescape with Social Location Marketing.

\section{Discussion and Conclusion}

A. Discussion

Based on the statistical test, it can be seen that servicescape have a positive impact and significant to the customer experience. Servicescape in cafe help customer envisions how products and/or services can create both positive experiences and value for them. A cafe that has a unique interior concept will be preferred by the customer. Customers looking for a cafe that provides a new situation, comports, allowing them to enjoy and relax, connecting with friends, and so on. To build loyalty, Cafe must become the third place in their life. Cafe must become place identity in relation to social enhancement of customers. This result in line with [46] that artifacts have a direct impact on the customer experience. servicescape as a driver of customer experience [47]. Moreover, Servicescapes not only influence the customer' value creation, but also have an impact on their future purchasing and consumption behavior [48].

Connections and interaction in the community are mainly based on location sharing. Indeed, check-in applications are one of the most frequently used features of location sharing. Check-in applications enable users to mark their locations share it on Social media, generally on Instagram, Facebook, path or Twitter. In this research, Two of the most popular social location sharing is Instagram and Facebook. Instagram is based on visual content. Respondent like using Instagram because the basic function is limited to the posting of pictures, video and also easy to share and connect to another account. Instagram bots take care of the activities of liking, following and commenting. Facebook has the capability to bring social location sharing into mainstream use by social network members.

Based on the statistical test, it can be seen that servicescape have a positive impact and significant to social location marketing. Customer will post or upload their 
activity (photo)in Cafe that has unique interior or posts their locaton.checking in at the cafe. They will recommend the location of a cafe. friends also can see the location posts of their contacts, friends who are interested in the cafe will find out and search the location of a cafe, write comments, rate locations, and like any related posts. According to [17], social location marketing can be a straight forward process of ensuring that location exists in the databases of the various tools, and then sitting back and waiting for people to interact with it on those platforms.

Through Social Media, cafe can build relationships with customers, and identify problems and solutions through collaborative interaction between online communities [49]. Social enhancement values refer to meeting new people, socializing, observing others, and meeting with friends [50]. Entertainment value refers to playing, relaxing, passing time when bored [51] and feeling less lonely [52].

Based on the statistical test, it can be seen that customer experience have a positive impact and significant to social location marketing. When customer relate with their friend or community (hangout) in a cafe and then they fell relax and enjoy, they will become a loyal customer. Customers will share and post the location of a cafe when they have experience positive moments and emotional states. When they have fun between friends, They will share the moment of happiness to other users. So that customer experience plays a key role in influencing social location marketing.

\section{B. Conclusion}

Servicescape has positive impact and significant to customer experience and social location marketing. It means businessman or marketer must provide unique servicescape (color, music, layout, aesthetics, seating, temperature, and cleanliness). When servicescape in cafe meets their expectation. It will affect consumers emotional responses and desire to stay in the cafe. A cafe will become the third place and place identity to customers.Customer experience have positive impact and significant to social location marketing. Customer will upload and share photo or video their location, and give information that Cafe has unique interior, delicious food, or memorable moment. They will recommend the location of a cafe in order to friends search, find out and check in to the location. They want to share memorable experience and happiness to their friend. So manager must know how to use and manage social media tools as social location marketing in order to make a campaign, communicate and attract people through social location sharing apps.

\section{References}

[1] Yuswohadi dan Gani, K. (2016) 8 wajah konsumen kelas menengah Indonesia, Gramedia, Jakarta
[2] Duff \& Phelps (2016), Industry Insights: Food Retail Industry Insights -2016

[3] Parasuraman, A., Zeithaml, V. A., \&Malhotra, A. (2005). E-SQUAL: a multiple-itemscale for measuring consumer perceptions of servicequality. Journal of Retailing, 64 (1), 12-40.

[4] Baker, J. (1986), "The role of the environment in marketing services: the consumer perspective", in Czepiel, J., Congram, C. and Shanahan, J. (Eds), The Services Challenge: Integrating for Competitive Advantage, American Marketing Association Proceedings Series, Chicago, IL, pp. 79-84s

[5] Bitner, M.J. (1992), "Servicescapes: the impact of physicalsurroundings on customers and employees", Journal ofMarketing, Vol. 56 No. 2, pp. 57-71.

[6] Lasalle, D. and T. A. Britton (2002), Priceless: Turning Ordinary Products into Extraordinary Experiences. Boston: Harvard Business School Press

[7] Davis, S. and T. Longoria (2003), 'Harmonizing your touch points'.Brand Packaging Magazine, (January/February).

[8] Schmitt, B. (2011) Experience Marketing: Concepts, Frameworks and Consumer Insights, Foundations and TrendsinMarketing Vol. 5, No. 2 (2010) 55-112

[9] Ariely, D. and Z. Carmon (2000), 'Gestalt characteristics of experiences:The defining features of summarized events'. Journal of BehavioralDecision Making 13, 191-201

[10] Fredrickson, B. L. and D. Kahneman (1993), 'Duration neglect in retrospectiveevaluations of affective episodes'. Journal of Personalityand Social Psychology 65, 45-55.

[11] Andrade, E. B. and J. B. Cohen (2007), 'On the consumption of negativefeelings'. Journal of Consumer Research 34.

[12] Brakus, J. J., B. H. Schmitt, and S. Zhang (2008), 'Experiential attributes and consumer judgments'. In: B. H. Schmitt and D. Rogers (eds.): Handbook on Brand and Experience Management. Northampton, MA: Edward Elgar

[13] Pham, M. T. (2007), 'Emotion and rationality: A critical review and interpretation of empirical evidence'. Review of General Psychology 11(2), 155-178

[14] Ryu, K. Hye R L, And Woo G K. (2012). The Influence Of The Quality Of The Physical Environment, Food, And Service On Restaurant Image, Customer Perceived Value, Customer Satisfaction, And Behavioral Intentions. International Journal Of Contemporary Hospitality Management, Vol 24, No 2 , Pp 200-223.

[15] Mathwick. C. Malhotra. N And Rigdon. E. (2001). Experiential Value:Conceptualization, Measurement And Application In The Catalog AndInternet Shopping Environment. Journal Of Retailing , 39-59.

[16] Salt, S. (2011). Social Location Marketing: Outshining Your Competition On Foursquare, Gowalla, Yelp And Other Location Sharing. Usa: Que.

[17] Countryman, C.C. and Jang, S. (2006), "The effects of atmospheric elements on customerimpression: the case of hotel lobbies", International Journal of Contemporary hospitalityManagement, Vol. 18 No. 7, pp. 534-45.

[18] Barker, R.G. (1968), Ecological Psychology: Concepts and Methods for Studying the Environmentand Human Behavior, Stanford University Press, Palo Alto, CA.

[19] Kotler, P. (1974), "Atmospherics as a marketing tool", Journal of Retailing, Vol. 49 No. 4, pp. 48-64.

[20] Morrin, M. and Che 'bat, J. (2005), "Person-place congruency: the interactive effects of shopper style and atmospherics on consumer expenditures", Journal of Service Research, Vol. 8 No. 2, pp. 181-91.

[21] Areni, C.S. and Kim, D. (1994), "The influence of in-storelighting on consumers $=$ examination of merchandise in awine store", International Journal of Research in Marketing,Vol. 11 No. 2, pp. 117-125

[22] Areni, C.S. and Kim, D. (1993), "The influence ofbackground music on shopping behaviour: classical versustop-forty music in a wine store", Advances in ConsumerResearch, Vol. 20 No. 1, pp. 336-340 
[23] Bailey, N. and Areni, C.S. (2006), "When a few minutes sound like a lifetime: does atmospheric music expand or contract perceived time?", Journal of Retailing, Vol. 82 No. 3,pp. 189-202.

[24] Harris, L.C. and Ezeh, C. (2008), "Servicescape and loyalty intentions: an empirical investigation", European Journal of Marketing, Vol. 42 Nos 3/4, pp. 390-422.

[25] Reimer, A. and Kuehn, R. (2005), "The impact of servicescape on quality perception", European Journal of Marketing, Vol. 39 Nos 7/8, pp. 785-808.

[26] Wakefield, K.L. and Blodgett, J.G. (1996), "The effects of theservicescape on customers $=$ behavioral intentions in leisure service setting”, Journal of Services Marketing, Vol. 10.

[27] Namasivayam. K And Lin. I. Y. (2008). The Servicescape. P. Jones, Handbook Of Hospitality. 43-62.

[28] Elin Nilsson, David Ballantyne, (2014) "Reexamining the place of servicescape in marketing: a service-dominant logicperspective", Journal of Services Marketing, Vol. 28 Issue: 5, pp.374-379

[29] Schmitt. (1999). Experiential Marketing, How To Get Customer To Sense, Feel,Think, Act, Relate, To Your Company And Brand. New York: The Free Press.

[30] Dong, P. and Siu, N.Y.M. (2013), "Servicescape elements, customer predispositions and serviceexperience: the case of theme park visitors", Tourism Management, Vol. 36 No. June,pp. 541-551.

[31] Carbone, L.P. (2004), Clued In: How to Keep Customers Coming Back Again and Again,Prentice-Hall, Harlow.

[32] Meyer, C. and Schwager, A. (2007), "Understanding customer experience", Harvard Business Review, Vol. 85 No. 2, pp. 116-26.

[33] Johnston, R. and Clark, G. (2008), Service Operations Management: Improving Service Delivery, 3rd ed., Prentice-Hall, Harlow.

[34] Ufuk Durna, Bekir Bora Dedeoglu, Sevgi Balikçioglu, (2015) "The role of servicescape and imageperceptions of customers on behavioral intentions in the hotel industry", International Journal ofContemporary Hospitality Management, Vol. 27 Issue: 7, pp.17281748 ,

[35] Back, K.J. (2005), "The effects of image congruence on customers' brand loyalty in the upper middle-class hotel industry", Journal of Hospitality \& Tourism Research, Vol. 29 No. 4, pp. 448-467.

[36] Kandampully, J. and Hu, H.H. (2007), "Do hoteliers need to manage image to retain loyal customers?", International Journal of Contemporary Hospitality Management, Vol. 19 No. 6, pp. 435-443

[37] Burton, J. and Khammash, M. (2010), "Why do people read reviews posted on consumer-opinionportals?", Journal of Marketing Management, Vol. 26 Nos 3-4, pp. 230-255.

[38] Yavuz, R. And Toker,A. (2014) "Location sharing on social networks: implications for marketing",Marketing Intelligence \& Planning, Vol. 32 Issue: 5, pp.567-585.

[39] Papacharissi, Z. and Rubin, A.M. (2000), "Predictors of internet use", Journal of Broadcasting andElectronic Media, Vol. 44 No. 2, pp. 175196.

[40] Flanagin, A.J. and Metzger, M.J. (2001), "Internet use in the contemporary media environment", Human Communication Research, Vol. 27 No. 1, pp. 153-181.

[41] Lowry, P.B., \& Gaskin, J. (2014). "Partial Least Squares (PLS) Structural Equation Modeling (SEM) for Building and Testing Behavioral Causal Theory: When to Choose It and How to Use It," in IEEE Transactions on Professional Communication, 57 (2), pp. 123146 , June.

[42] Hair, J.F., Black, W.C., Babin, B.J. and Anderson, R.E. (2013), Multivariate Data Analysis: PearsonNew International Edition, 7th ed., Pearson, Harlow.

[43] Hair, Joseph F. Jr., Christian M. Ringle, dan Marko Sarstedt. (2011). "PLS-SEM: Indeed a Silver Bullet", Journal of Marketing Theory and Practice 19:139-13

[44] Edvardsson, B and Enquist, B. (2005) Co-Creating Customer Value Through Hyperreality in the Prepurchase Service Experience, Journal of Service Research . November 2005, DOI: $10.1177 / 1094670505279729$
[45] Teresa Fernandes \& Sara Neves (2014): The role of servicescape as a driverof customer value in experience-centric service organizations: the Dragon Football Stadium case,Journal of Strategic Marketing.

[46] Pareigis, J., Echeverri, P., \& Edvardsson, B. (2012). Exploring internal mechanisms formingcustomer servicescape experiences. Journal of Service Management, 23, 677- 695.

[47] Tsimonis, G. and Dimitriadis, S. (2014), "Brand strategies in social media”, Marketing Intelligence \& Planning, Vol. 32 No. 3, pp. 328344.

[48] Pentina. I, Prybutok. V.R., Zhang. X, (2008). The role of virtual communities as shopping reference groups. Journal of Electronic Commerce Research, 9(2), 114-136.

[49] Dholakia, U.M., Bagozzi, R. and Pearo, L.K. (2004), "A social influence model of consumer participation in network- and smallgroup-based virtual communities", International Journal of Research in Marketing, Vol. 21 No. 3, pp. 241-263

[50] La Rose, R. and Eastin, M. (2004), "A social cognitive theory of internet uses and gratifications", Journal of Broadcasting and $\begin{array}{llllll}\text { Electronic Media, } & \text { Vol. } 48 \text { No. 3, pp. } 358-377\end{array}$ 